SCJR 16, no. 1 (2021): 1-3

\title{
David B. Ruderman Missionaries, Converts, and Rabbis: The Evangelical Alexander McCaul and Jewish-Christian Debate in the Nineteenth Century
}

(Philadelphia: University of Pennsylvania, 2020), vii + 251 pp.

\author{
YAAKOV ARIEL \\ yariel@email.unc.edu \\ University of North Carolina at Chapel Hill, NC 27599
}

Anyone interested in Jewish-Christian relations, as well as in the history of missions, will welcome Missionaries, Converts, and Rabbis. It is a remarkable book. Through the exploration of the work and thought of Alexander McCaul (1799-1863), an outstanding British missionary leader and writer, the author skillfully resurfaces a much larger story. The book explores the history of missions to the Jews in the $19^{\text {th }}$ century, the impetus for evangelizing Jews, the fieldwork that the missions carried out, and the literature they produced. Ruderman also pays attention to Jewish converts, their thoughts and careers (chapters 4 and 6), as well as to the competing ideas on how to approach the Jews within the Evangelical community that sponsored the missionary enterprises (chapter 5). Likewise, the book examines Jewish reactions to the missionary endeavor, especially to McCaul's ideas and writings (chapters 7 and 8).

This is a comprehensive and thorough study of a particularly important topic in the history of Judaism, as well as of Christianity, in the modern era. Organized, systematic attempts at evangelizing Jews came about with the rise of the Pietist movement in continental Europe at the turn of the $18^{\text {th }}$ century and was followed, with much energy, by Evangelicals in Britain a century later. The missions meshed with and gave voice to the Messianic theology of Pietists and Evangelicals and their new, or renewed, understanding of the role of Jews in God's plans for humanity.

Missions were more than agencies aimed at Christianizing Jews. They served as double-edged embassies, stirring Protestant interest in the Jews, and the prospect of their conversion to Christianity and return to Palestine, as well as propagating the Christian faith in its Protestant messianic version among the Jews. From their own perspectives, missionaries were devoted to the Jews. They were working to aid the Jews materially and spiritually, and they often defended the Jews from what 
they considered to be malicious accusations, such as blood libels. At the same time, missionaries, such as McCaul, manifested a dismissive attitude toward rabbinic literature and published tracts attacking the Talmud (chapter 1). Utilizing his familiarity with Jewish commentators to make a case for the evolutionary nature of Jewish law, McCaul characterized (rabbinic) Judaism of his day as far removed from biblical religion and as incapable of offering its adherents spiritual salvation. With the exception of the Decalogue, none of the commandments were abiding. Jewish thinkers, especially among the emerging reformist movements, took exception to the attacks on rabbinic Judaism.

The Jewish elite often looked at the missions, which spread throughout the Jewish world in the $19^{\text {th }}$ century, as an insult and a threat. Missionaries brought Jews into their orbit by offering medical and financial assistance, as well as educational opportunities. They also distributed tracts and engaged Jews in conversations. Missionaries were aware that many Jews, especially the young and dynamic, were searching for new ways of life and wishing to improve their lives within larger European or American contexts. The missions offered one such new context. Though it is one that only a minority chose, many explored them, a reality that made the Jewish elite very uncomfortable. The missions proliferated at the same time that Jewish thinkers were themselves working to modernize their tradition and re-interpret and reconfigure their own faith. Jewish writers who responded to the Christian evangelists therefore walked a fine line between their own reformist agenda and their opposition to the alternative that Christian missionaries offered.

Jewish maskilim, followers of the Jewish Enlightenment, who responded to McCaul's tracts, seriously engaged with him. Isaac Baer Levinsohn, an East European maskil, tried to disqualify McCaul as a scholar of rabbinic Judaism, claiming that McCaul was not fully familiar with Jewish texts and their meanings (chapter 7). Another East European Jewish maskil, Samuel Joseph Fuenn, wrote a comparative history of Christianity and Judaism, deeming Judaism the superior religion (chapter 8). Raphael Kasin, a reformist rabbi in Bagdad and in Aleppo, came out with a daring formula for his time. Constructing a didactic fable, the Syrian rabbi defended Judaism and presented it as a noble religious tradition, though he rejected claims of its exclusivity or superiority. Judaism, he asserted, was a universalist tradition that promoted the redemption of all good people, not only Jews. Likewise, he presented Christianity as a noble religion for Christians, offering all that they desired religiously (pp. 188-89). Such a benevolent outlook would only become prevalent a century later, in the last few decades of the $20^{\text {th }}$ century, when a movement of Jewish-Christian dialogue and reconciliation appeared and which cultivated a measure of respect in the manner that Christians and Jews related to each other.

As erudite and innovative as they might have been, the Jewish anti-missionary tracts had little influence on the choices that Jews made when considering the option of embracing Christianity. The tracts enjoyed limited circulations and were often published belatedly, even after their authors' death. The one exception were the missionaries, who read all the literature Jewish opponents of missionary activities wrote about them, often quoting from such attacks in their literature. It seems 
that Jewish thinkers wrote not so much to dissuade their coreligionists from converting to Christianity but rather to define their faith in face of growing alternatives both within the fold and outside of it.

The exploration of the Jewish intellectual reactions to missionary writings is one of the highlights of this outstanding book. As Missionaries, Converts, and Rabbis demonstrates, missions have posed serious challenges and stirred strong reactions in the Jewish community. However, Jewish, as well as Christian, historians have, by and large, overlooked those highly important endeavors that have served as major venues of interaction and dialogue between Protestant Christians and Jews. This book is an enormous contribution to the field and its available literature. Likewise, it serves as a model and inspiration for historians, who, hopefully, decide to pursue research on the subject. David Ruderman should be commended for his study, which has the potential to transform the field. 